\title{
Material Requirement Model of Coconut Flour Production and Performance Testing based Multi User in North Sulawesi
}

\author{
Harson Kapoh \\ Dept. of Informatic Engineering \\ Manado State Polytechnic \\ Manado 95252 North Sulawesi \\ Indonesia
}

\author{
Edwin Stephanus \\ Lumunon \\ Dept. of Informatic Engineering \\ Manado State Polytechnic \\ Manado 95252 North Sulawesi \\ Indonesia
}

\author{
Olga Melo \\ Dept. of Informatic Engineering \\ Manado State Polytechnic \\ Manado 95252 North Sulawesi \\ Indonesia
}

\begin{abstract}
Production of coconut flour is often hampered due to the lack of production control and inventory control are well on coconut flour industry that often cannot cover the export demand. For that coconut flour industry in North Sulawesi require tools in running the business, one of which is a computer-based system. The problem in this research is how to make the material requirement model of coconut flour production based multi-user to control the coconut flour industrial centers in North Sulawesi and how to test the model. The generated in this study have been through a survey in the industrial district of coconut flour to get the data that will be used analysis, so that a complete picture processing system coconut flour and can describe the problem also the solution clearly in order to get the system needs a model along the test by using a test black box the program and test performance using respondents. This above is justified because there is a relationship between respondents who selected models of applications that have been developed. The collected data is then analyzed and designed using some design method that is data flow diagrams, use case diagram, entity relationship diagrams and material requirements planning methods. The results of the testing indicate all functions on the system works well and test the respondent for 30 and 60 minutes resulting in a $60 \%$ and $63 \%$ of respondents were taken as many as 30 answered easily using the model application.
\end{abstract}

\section{Keywords}

Model, requirement, coconut flour, multi-user, testing

\section{INTRODUCTION}

Indonesia is a big country and a wealthy country, a country with a population of approximately 250 million, it has a lot of natural resources and other potentials that could make Indonesia become economically advanced countries so as to create a just and equitable economy. One agricultural commodity that has a strategic position in Indonesia is palm plants (Cocas nucifera. $\mathrm{L}$ ). This crop ranks second only to rice crops in terms of employment, reaching seven million people across Indonesia [1].

North Sulawesi's population currently numbering more than 2 million inhabitants spread over 15 (fifteen) of the districts and cities. Coconut flour as one of the very oil derivative products has great potential to become the industry's demand for export very large. So far, farmers rely palm oil production is only made copra alone. So the farmers' income is only focused on income from the sale of copra alone when farmers can produce their own flour with the results of the coconut oil itself or from buying oil from fellow farmers. When farmers produce coconut flour it means that farmers can benefit more than just making copra alone and could open up the jobs for the community.

References [10] found to be able to do the production with productive then you should have a production schedule to anticipate demand, what more demand for products that are more and more so that the allocation of raw materials, labor costs and requires good planning.

As well as the manufacture of coconut flour in addition to knowledge of how or procedures produce coconut flour is good, business people or entrepreneurs also requires knowledge, how so as to meet the demand of coconut flour of consumers, let alone demand trends in the greater or less in a period a period of 6 months ahead up to 1 year. Producing good is based on the planning and controls so that the use of raw materials, and labor costs can be efficient and effective [2].

Now this entrepreneur who produces coconut flour in North Sulawesi are still a little while oil production in North Sulawesi as many as 277719 tons per year. Therefore, we think there are many more opportunities if you want to produce coconut flour on an industrial scale, plus the need for very high coconut flour which is to meet the demand for exports. For that it is important to produce a model of tools in the field of information technology to run the desiccated coconut industry, especially in the oil centers in North Sulawesi. This thinking is also supported with research conducted by T.M.A. Ari Samadhi that the production of coconut flour is often hampered due to the lack of production control and inventory control are well on coconut flour industry so it can not cover the export demand due to frequent shortages of raw materials or the accumulation of raw materials [11]. There are so many countries in Europe and Africa and the Middle East needs to be worked into the export destination Sulawesi Utara [12].

Information systems development methodology has been very good since the beginning of 1970 so as to develop a model of information becomes more easily [4]. Many companies today are started up and implement information technology due to the fact of information technology can assist in decision making, planning and transactions for the management of a company in a fast, accurate and relevant [6]. The Company is no longer thought to be wearing or not the technology but how extensive its usage to help productivity and competitive advantage of the company's competitors. 
This research should produce a product resulting information technology to assist in the control of coconut flour producer, in order to avoid a shortage of raw materials, production schedule can be implemented with sales and order entry will be smoother, as well as the delivery of goods will be well coordinated. So that the management in producing flour Kelps will become easier in the control and enabled entrepreneurs, managers better understand how to control coconut flour with productive industry, especially relating to the production.

For that reason, should conduct research in the field of information technology to produce a "Design Model Material Requirement Coconut Flour Production and Testing of Performance-based Multi User" that can be used to help process the coconut flour industry.

Based on the background noted above then be made to the formulation of the problem as follows:

How to design a model material production requirement of coconut flour-based multi-user to control the production of coconut flour industrial centers in North Sulawesi.

How to test a production model based on multi user coconut flour production control for industrial centers in North Sulawesi coconut flour.

The purpose of this study is

- Produce a production application that helps in the production control.

- $\quad$ Produce material inventory control applications

- Generate an application order of coconut flour.

- Produces application recording of financial transactions.

- Produce models or applications that have been tested.

\section{RESEARCH METODOLOGI}

Problems that have been identified in the beginning will be solved with the help of appropriate research methodologies.

\subsection{Location and Time}

The location and time of the study conducted in the North Sulawesi and time for 1 year.

\subsection{Stage of Research}

Stages of the planned studies are as in Fig .1.

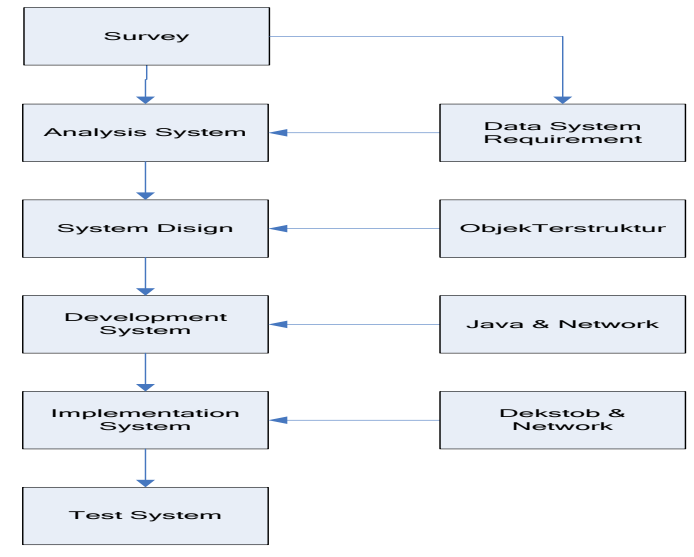

Fig 1: Block stages of research
Fig. 1 is a block diagram above illustrates the stages of research that should be conducted during the study.

\subsection{Research Methods}

The method used for this study is

- Methods of field studies (observation study) and literature (library study). This method is used to identify the problem.

- Interview method, used to determine the system to be built.

- Questionnaire method, used to determine the level of

- Employee participation in providing information.

- Method of architecture is the method that will be used to describe the system.

- Functional testing using black box to see the results when the system is run if the system can receive data, whether the server is responding and displays information in accordance with the reality on the ground.

- Evaluate the interface using respondents with a questionnaire to test the performance whether the system easy to use.

\subsection{Data Collection Techniques}

Data collected by the way,

- Interviews, to obtain data such as system sales, production, finance, raw materials and supplies

- Observation, the working mechanism on coconut flour industry

\subsection{Study Design}

The study design consists of:

- Literature review

- Studies conducted to collect the reference to be used as the material resources that include: hand books, journals, papers / articles and previous studies associated with the system will design and applied

- Analysis, design and implementation of applications

- Analysis of system performance

- Preparation of reports

\subsection{Research Instrument}

This study requires several instruments to support analysis and research:

- $\quad$ - A set of computer or laptop (minimum of an Intel 3)

- - Software support: Java and MySQL

- $\quad$ Tools: cable network and printer

\subsection{Analysis System Design}

Some of the analytical tools needed to help in the analysis in this study are as follows [9]:

- Flow chart, used to analyze the system and program

- Data Flow diagrams, used to analyze the data flow that occurs in the system will be built 
- Entity Relationship Diagram, is used to analyze the relationships between the entities in the system to be built

- Use case diagram, used to analyze who is entitled to use the system functions.

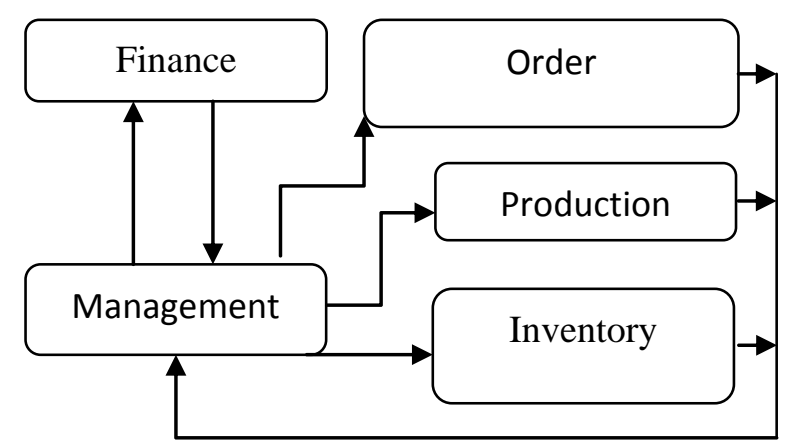

Fig 2: The architecture system

The design of the system architecture proposed in this study as in Fig. 2. The design of the proposed system is based on a unified control on the production of coconut flour as in Fig. 3

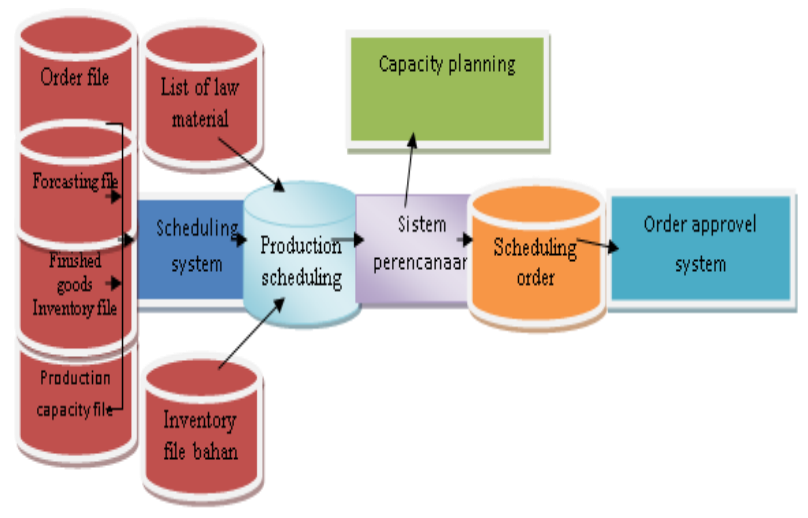

Fig 3: Integrated Method

The proposed control system is a production system with an integrated approach so as to produce the files: orders, inventory, production capacity, a list of materials and supplies [6]. Fig. 3 overall systems built to be based on material requirements planning methods.

\section{RESULTS AND DISCUSSION}

\subsection{Results}

\subsubsection{Flowchart}

In general the survey results in the area of Minahasa in North Sulawesi, the production of coconut flour is not using the computer-based system that is integrated. For that of the needs assessment, the system design can be seen in the system flowchart below:

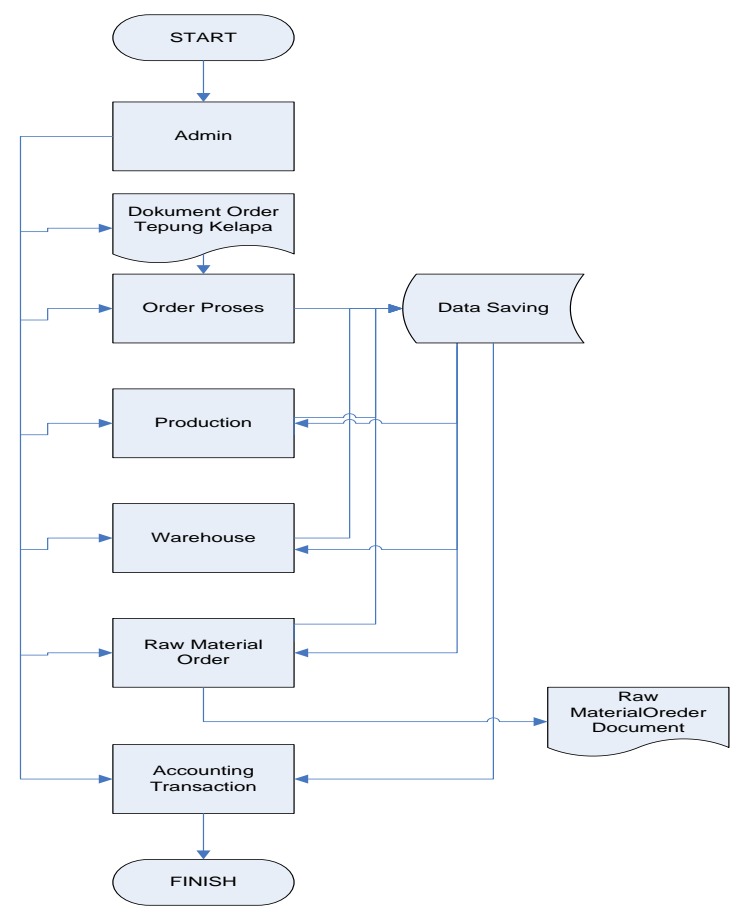

Fig 4: Flowchart system

Flowchart in Fig. 4 shows the working procedure of the system that will be built are all ordering document are inserted at booking system desiccated coconut , this reservation will be processed and the data will be viewed by the admin part of the production how that will be produced and it will be valuable information for the production and warehouse, so the warehouse can prepare raw materials for production and insufficient when it will be done ordering raw materials made of coconut and booking documents . All financial transactions will be recorded and processed within the finance department. Admin of each section may be able to use this system. 


\subsubsection{Data Flow Diagram}

Based on data obtained from a survey conducted using the data flow design data flow diagram [9].

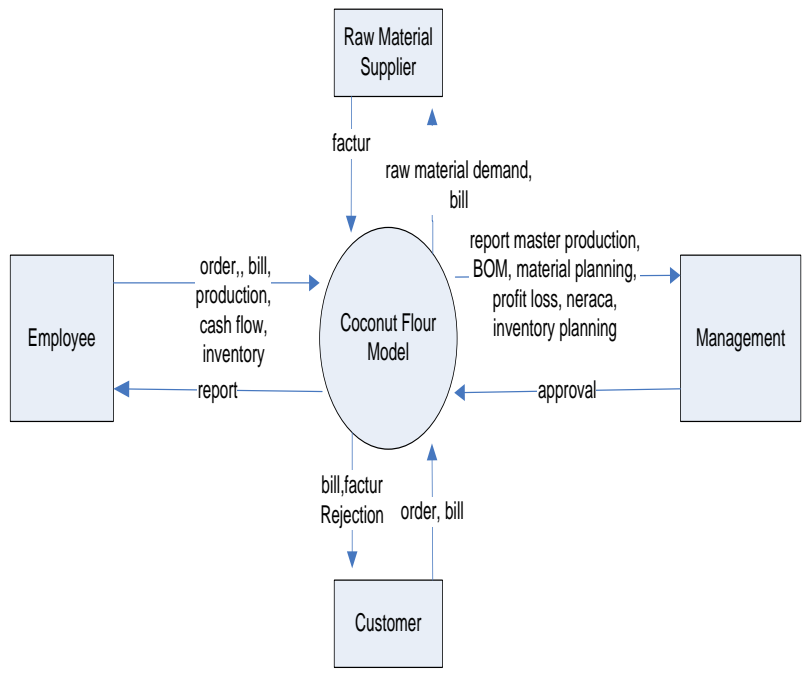

Fig 5: Diagram context coconut flour production control system

Fig. 5 is a data flow diagram of the system context analysis results, visible outside entities related to the existing four models namely; customers, suppliers and management. Each has a role and purpose of the system.

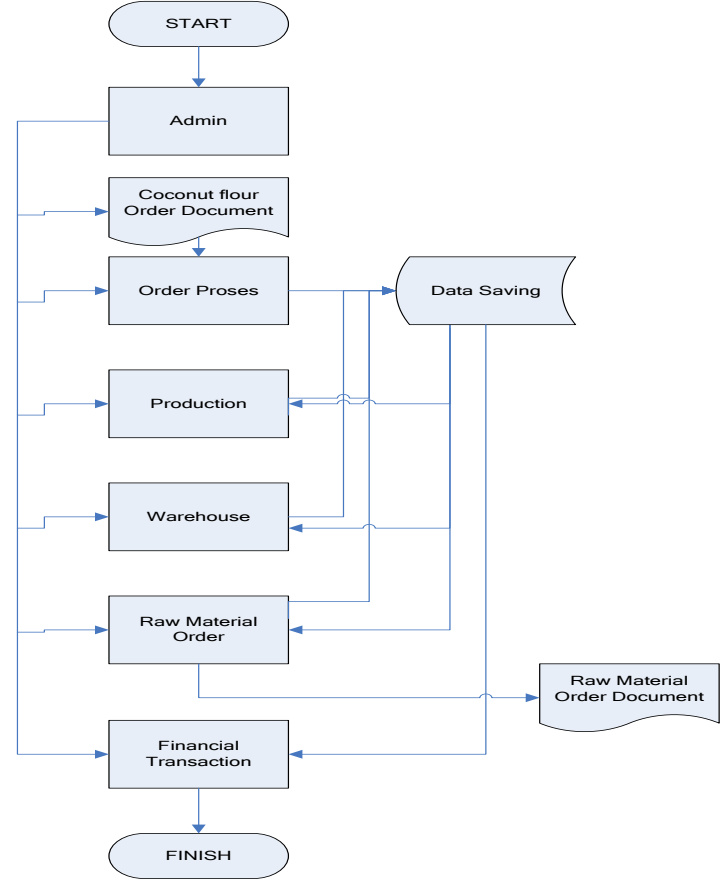

Fig 6: Diagram level 1 system

Fig. 6 is the result of decomposition of the data flow diagram context produces four processes, namely: orders, production, inventory and finance.

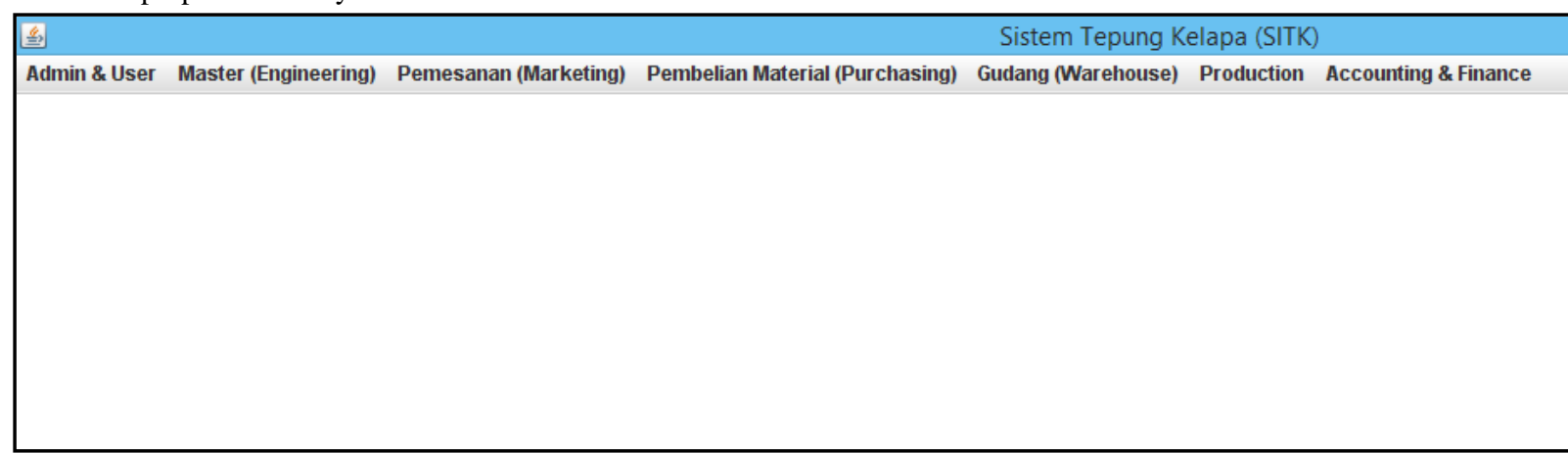

Fig 7: Initial Display Interface

\subsubsection{Interface}

System or application interface is derived from the analysis and system design. This system is called the system information tepung kelapa or SITK. Fig. 7 is a system interface of the application. It is included on the menus: user, master, ordering, production, purchasing, warehouse and financial records.

\subsubsection{Testing}

Testing the system using black box testing and test respondents. Tests on a model using black box method is a method of testing the model or program without considering the structure of the program. Black box method used in this study was to determine whether the program can receive data input, process the data and generate the appropriate information and the program was not error [13].
Table 1. Black box test

\begin{tabular}{|c|c|c|c|}
\hline $\begin{array}{c}\text { Test } \\
\text { Class }\end{array}$ & $\begin{array}{c}\text { Testing } \\
\text { Techniq } \\
\text { ues }\end{array}$ & $\begin{array}{c}\text { Expected } \\
\text { Result }\end{array}$ & Test Result \\
\hline $\begin{array}{c}\text { Authe } \\
\text { ntifik } \\
\text { asi } \\
\text { Admi } \\
\text { n }\end{array}$ & $\begin{array}{c}\text { Black } \\
\text { Box }\end{array}$ & $\begin{array}{c}\text { Admin can } \\
\text { login, can } \\
\text { add to the } \\
\text { user. }\end{array}$ & $\begin{array}{l}\text { Checking system } \\
\text { admin login process, } \\
\text { successful or not, and } \\
\text { then save the admin } \\
\text { session when the login } \\
\text { process, and shut } \\
\text { down the session } \\
\text { when administrators } \\
\text { have logged out, so } \\
\text { that the system cannot } \\
\text { be opened again } \\
\text { unless must log back } \\
\text { in. Admin can add } \\
\text { users to the system ( } \\
\text { successful ) }\end{array}$ \\
\hline
\end{tabular}




\begin{tabular}{|c|c|c|c|}
\hline $\begin{array}{c}\text { Authe } \\
\text { ntifik } \\
\text { asi } \\
\text { user }\end{array}$ & $\begin{array}{c}\text { Black } \\
\text { Box }\end{array}$ & $\begin{array}{c}\text { Users can } \\
\text { log in and } \\
\text { access a } \\
\text { menu } \\
\text { which } \\
\text { allowed }\end{array}$ & $\begin{array}{c}\text { The system checks the } \\
\text { login process for each } \\
\text { user permissions on } \\
\text { the master and the sale } \\
\text { ( successful) }\end{array}$ \\
\hline $\begin{array}{c}\text { Data } \\
\text { Proce } \\
\text { ssing }\end{array}$ & $\begin{array}{c}\text { Black } \\
\text { Box }\end{array}$ & $\begin{array}{c}\text { Admin and } \\
\text { user can } \\
\text { perform } \\
\text { data } \\
\text { processing } \\
\text { on the } \\
\text { master and } \\
\text { booking }\end{array}$ & $\begin{array}{c}\text { The system can } \\
\text { display, add data } \\
\text { admin , user, master } \\
\text { and booking coconut } \\
\text { flour ( successful ) }\end{array}$ \\
\hline
\end{tabular}

Table. 1 is a summary of the results of black box testing method to test the entire system such as logins and data processing with the intended results.

Test respondents using performance testing for functional model is a test method for functional purposes of software [13]. Scenario testing using two respondent groups. Each of these 30 people, and by using these respondents do data input into the processes that exist in the software from one menu to another menu with no formal training first on the respondents, only done explanation of how to use and respondent tried for 30 and 60 minutes, Furthermore, they are asked to fill out questionnaires with questions as follows: after you try the app how do you think the mechanism of production control system applications coconut flour with 4 possible answers that is very easy, easy, quite complicated, and complicated.

This test using nonrandom sampling method is by using purposive sampling technique [13]. The distribution of data for sampling based on the number of respondents who had determined that 30 people who master the computer-based technologies. According to Y. Erna, the ability of a good person uses computer technology will affect the use of an application model [14]. This shows that there is a relationship between a model or application with the mastery of technology. This statement into consideration the determination of the characteristics of the respondent. The characteristics of respondent who meet the requirements of the characteristics of the population, Regardless of where the origin of the subject to the requirements that meet them as objects of the population is Able to use windows based, student status and has a laptop or pc itself. Samples taken as many as 30 of participants for the research object .

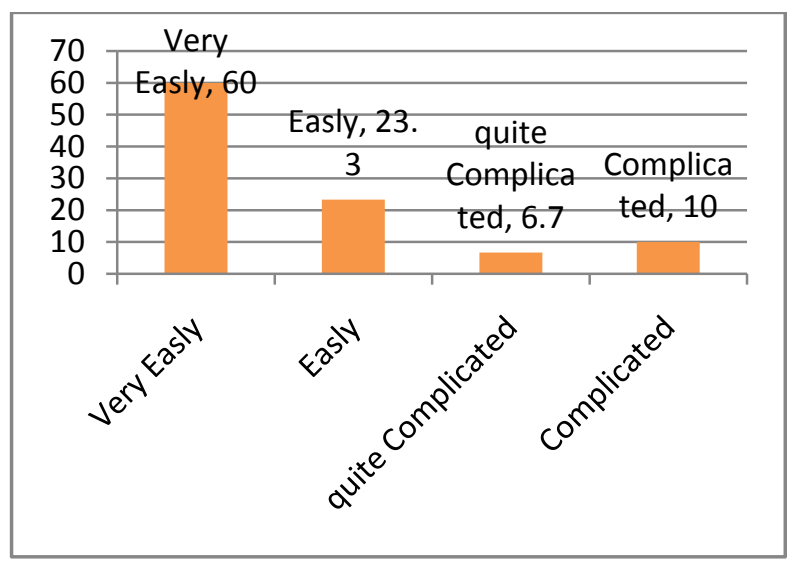

Fig 8: Diagram of respondents 30 minute test

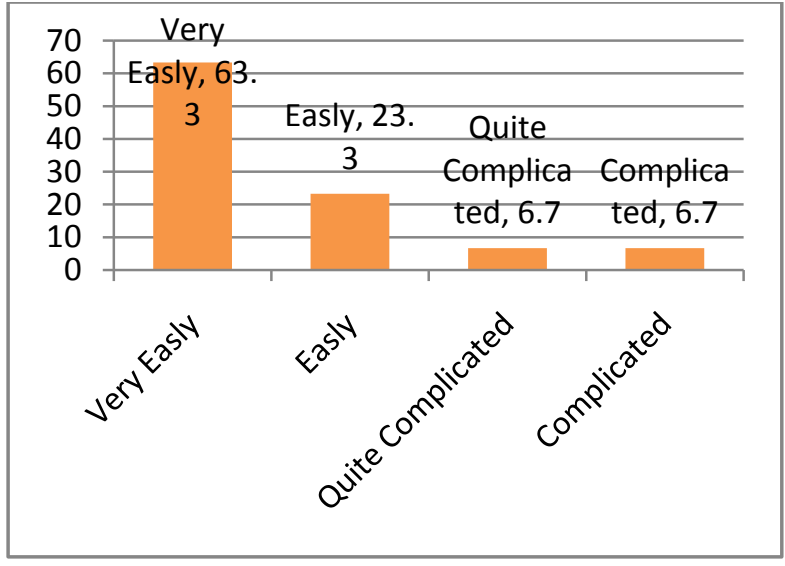

Fig 9: Diagram of respondents 60 minute test

Fig. 8 is a diagram showing the test results of 30 respondents to answer $60 \%$ answered very easily , $23 \%$ answered easily , $7 \%$ answered quite complex, and $10 \%$ answered complicated.

Fig. 9 is a diagram showing the test results of 30 respondents to answer $63 \%$ answered very easily, $23 \%$ answered easily, 7 $\%$ answered quite complicated, and $7 \%$ answered complicated.

\subsection{Discussion}

Based on preliminary research results obtained coconut flour a production model that is expected to help industry coconut flour as software tools in the management so as to increase the output of the production process and timely order fulfillment coconut flour can be increased due to the need of raw material can be in the know faster. Applying this app does require a change in the booking service procedures and how the system works desiccated coconut industry. The design of the booking service procedures and how the system has not been done in this study.

To see the functionality of the production model of coconut flour-based multi user has performed testing nonprobability sampling using two groups each of 30 respondents without doing a test distribution data such as the test of probability sampling due to sampling taken to answer the questionnaire considered homogeneous with traits surely i.e. have the ability to use windows-based computers, have laptop or own pc and a student and obtained the test results as in Fig. 8 is a diagram of test respondents showed that $60 \%$ of respondents said the system easy to use application and Fig. 9 shows that $63 \%$ of respondents said the application system is easy to use means to respondents who have characteristics and abilities using a computer running Windows, the status of students and has laptop itself, having tried the application then they concluded by giving an answer that the model material requirement of production of coconut flour is easy used.

Test respondents who had done the first and second shows that the respondents stated that the application is easy to use, this shows that the mastery of respondents in a technology that respondents have a laptop so they are considered master the technology hardware and use windows means mastering software technology is very influential in the percentage of answers with results above $50 \%$ ie $60 \%$ and $63 \%$. Influence user interface application developed using the display window-like applications that are already known to the respondents, the windows are very influential. Is consistent with that put forward by Y. Erna [14] that currently uses a system or a computer-based model, the mastery of the 
technology by the user will affect the speed of the mastery models stretcher by the user. In this study, the test was performed using the relationship between the performance of the application model which has been developed with usercontrolled technology. Model applications that have been built in these studies show that the model application to qualify the quality of an information system that can be used in real conditions. According to Yusof et al [8], to determine whether or not the information system quality can be judged from the ease of use, easy to learn, response time, usefulness, availability, flexibility, and security as well as regarding the linkage of the features of the system include system performance and user interface. Still according to Erna Y. [14] if the quality of the system better, it will also lead to a good response from the users and the result will be otherwise when the system is not good. This opinion is also in line with the image P. [5] that users will be satisfied with the system because the system is reliable, flexible, and has a simple interface and fast response time. Good response from the respondent or users in this test showed that the quality system is good with a good performance anyway.

The test results that have been done by the two groups of respondents with the same characteristics there are differences in the results. The difference of $3 \%$, and this may be due to an increase in the time of 30 minutes in groups of first responders to 60 minutes are given to the second group of respondents to use a model or application before answering questions.

The increase of $3 \%$ may also be caused by the respondent or users who are students allow them quickly to adapt to the system. Thus affecting the response that the system is easy to use. The test results of respondents currently be accepted that the application is easy to use even if has not been tested in the industry but is also expected when the application is used then the conditions and characteristics similar to the results of research will have an impact on the ease of the system to be used on actual conditions.

Tests using two groups also shows that there are still shortcomings that applications not meet the quality expected ideal so there needs to be improvement of performance models to improve the ability of the program to increase the functionality of the program is also so easy to use.

The test results of respondents currently be accepted that the application easier to use and is also expected when the application is used then the conditions and characteristics similar to the results of research will have an impact on the system's ease of use.

\section{CONCLUSION}

These requirement material models are developed for their inability to issue coconut Flour Company in North Sulawesi Indonesia to meet the needs of raw materials for production. Model material requirement results of this study can help to manage the production of coconut flour because of the design of an integrated system that was created allows any operator or administrator has access rights to manage their respective functions and information from an interconnected parts of the company. This model can be used well by the company of coconut flour to help the productivity needs of raw materials and production because it was through the study of the test with the black box method or methods of non-random probabilistic with the results of the first group $60 \%$ and the second group $63 \%$ of respondents said that this model is easy used. When the operator who will use this model has characteristics similar to the respondents who participated while testing the more it will bring a positive impact to the company of coconut flour to meet export demand and coconut flour that have been constrained by the management needs of raw materials for production are maximal. The conclusion of this study is

\section{ACKNOWLEDGMENTS}

Thanks to the Manado State Polytechnic Leadership, Center for Research and friends who have helped.

\section{REFERENCES}

[1] H. Amir, M. Amelia. Dan A. Supu, Pengaruh Pasokan Bahan Baku Kelapa Terhadap Produksi. Tepung Kelapa di PT. Tri Jaya Tangguh Isimu. Kabupaten Gorontalo, Retrieved kim.ung.ac.id/index.php/KIMFIIP/article,2013.

[2] D.D. Bedworth, J. E. Bailey, 1987 Integrated Production Control System, John Wiley \& Sons.

[3] Direktorat Penelitian dan Pengabdian pada Masyarakat, Panduan Pelaksanaan Penelitian dan Pengabdian pada Masyarakat di Perguruan Tinggi, 2013.

[4] Jogiyanto. 2005 Analisis dan Disain Sistem, Penerbit Andi,.

[5] K. Harson, 2008 "Penerapan Sistem Informasi berbasis MRP pada Perusahaan Manufaktur", Polimedia.

[6] M. Raymond Jr, G. D. Scell. 2004 Managemen Information Sistem, New Jersey, Prentice Hall.

[7] Indonesia,http://badanbahasa.kemdiknas.go.id. Tanggal akses 30 April 2013 pada pukul 21.00.

[8] M. M. Yusof, R. J. Paul and L. K. Stergioulas, 2006. Towards a Frameworkfor Health Information Systems Evaluation, In Proceedings of the 39th Hawaii International Conference on System Sciences

[9] S. Rosa, Rekayasa Perangkat Lunak, Bandung, Penerbit Modula, 2011.

[10] Sipper \& Bulfin Jr, 1997. Production Planning, Control, and Integrations, McGraw Hill,1997.

[11] T.M.A.Samadhi, A. Soetrisno \& B. Padmodjo, "Pembuatan Rencana Produksi Tepung Kelapa Jenis Fine dan Medium Serta Mekanisme Pengendaliannya", Journal of RealTech, Manado, Penerbit Fakultas Teknik Universitas Katolik De La Salle Manado, 2007, in press

[12] http://www.republika.co.id/berita/nasional/daerah/14/06/ 12

[13] R. Pressman. 2002 Rekayasa Perangkat Lunak, Andi.

[14] Y. Erna, Analisis Faktor Determinan Penggunaan Sistem Aplikasi Pemeriksaan Laporan Keuangan dan Implikasinya, JNTETI, Vol. 03, No. 2, Yogjakarta , 2014 